\title{
Fluoride intake in preschoolers from two different communes in Santiago, Chile
}

\author{
Ingestão de flúor em crianças pré-escolares de duas \\ comunidades em Santiago, Chile
}

\begin{abstract}
Purpose: To determine the fluoride intake in three- to five-year-old preschool children from two communes in Chile, one with a non-fluoridated public water supply (Maipú) and the other with fluoridated public water supply since 1996, at a fluoride concentration of $0.6 \mathrm{mg} / \mathrm{L}$ (Peñalolen).

Methods: Cross-sectional, observational design. The sample population was composed of 200 three-to-five-year-old children attending four kindergartens in the Santiago Metropolitan Region, Chile, in the communes of Maipú and Peñalolen. Intake of fluoride was measured in a morning urine sample by using an ion-specific electrode and creatinine concentration. The fluoride intake from other sources was estimated from the parents' and educators' survey answers.

Results: The daily dose of fluoride intake (DDI) for all Maipú preschoolers was $0.021 \mathrm{mg} \mathrm{F} / \mathrm{kg}$ body weight $(\mathrm{bw}) /$ day, a value less than the optimal dose, which is 0.05 to $0.07 \mathrm{mg} \mathrm{F} / \mathrm{kg}$ bw/day. The DDI for the Peñalolen sample reached $0.066 \mathrm{mg} \mathrm{F} / \mathrm{kg}$ bw/day. There is a contribution from fluoride toothpaste ingestion of $0.019 \mathrm{mg} \mathrm{F} / \mathrm{kg} \mathrm{bw} /$ day in Maipú and $0.017 \mathrm{mg} \mathrm{F} / \mathrm{kg} \mathrm{bw} /$ day in Peñalolen. The overall frequency of daily brushing was 3.15 times, during which $31 \%$ of Maipú children and $33 \%$ of Peñalolen children ingested toothpaste. The estimated amount of fluoride intake from toothpaste and tea consumption explained the contribution of fluoride not coming from fluoridated water.
\end{abstract}

Conclusion: The fluoride ingestion from water and other sources in the preschool commune of Peñalolen is much higher than the fluoride intake in preschoolers of the Maipú district.

Key words: Fluoride; children; ingestion

\section{Resumo}

Objetivo: Determinar a ingestão de flúor em pré-escolares de três a cinco anos de idade, de duas comunidades de Santiago, Chile, sendo uma com abastecimento público de água não fluoretada e outra com água fluoretada.

Metodologia: Estudo observacional, transversal. A amostra foi composta de 200 crianças de três a cinco anos de idade, com boa saúde geral, de baixo nível socioeconómico, que frequentavam quatro jardins de infância da Região Metropolitana de Santiago, Chile. Duas escolas estavam localizadas em Maipú, que não tem água pública fluoretada e duas escolas estavam localizadas em Peñalolén, com água fluoretada desde 1996, em uma concentração de flúor de $0,6 \mathrm{mg} / \mathrm{L}$. A ingestão de flúor foi medida em uma amostra de urina da manhã, medindo-se o flúor com eletrodo íon-específico e concentração de creatinina com o produto comercial VALTEK (R). A ingestão de flúor estimado de outros veículos foi avaliada por questionários aos pais e educadores.

Resultados: A dose diária de ingestão de flúor (DDI) para todos os pré-escolares Maipú foi $0,021 \mathrm{mgF} / \mathrm{kg}$ peso corporal $(\mathrm{pc}) / \mathrm{dia}$, um valor menor do que a dose ideal de flúor, de 0,05 para 0,07 mg F/ $\mathrm{kg}$ corporal/dia. Na amostra de Peñalolen a DDI atingiu $0.066 \mathrm{mg} \mathrm{F} / \mathrm{kg}$ corporal/dia, dentro dos parâmetros ideais. Houve cerca de 0,019 mg F/kg bw/dia em Maipú e $0.017 \mathrm{mg} \mathrm{F} / \mathrm{kg}$ corporal/dia em Peñalolén proveniente da ingestão de creme dental com flúor. A frequência de escovação diária foi de 3,15 vezes, sendo que 31\% das crianças de Maipú e 33\% das crianças Peñalolen ingeriam creme dental. Cerca de $46,5 \%$ das crianças bebia chá todos os dias. A estimativa para a quantidade de ingestão de flúor do creme dental e consumo de chá explica a contribuição de flúor não proveniente de água fluoretada.

Conclusão: A ingestão de flúor da água e outras fontes no município de Peñalolen pré-escolar é muito maior que a ingestão de flúor em pré-escolares do distrito de Maipú.

Palavras-chave: Flúor; crianças; ingestão

\author{
Ismael Yévenes a \\ Barbara Henández b \\ Alfredo Apip Ramos b \\ Miguel Neira Jara ${ }^{a}$ \\ Paula Maass Wolfenson a \\ Ljubica Petrasic a
}

a Department of Chemical, Dental School,
University of Chile, Santiago, Chile
b Department of Restorative Dentistry, Dental
School, University of Chile, Santiago, Chile

\author{
Correspondence: \\ Ismael Yévenes \\ Department of Chemistry, Dental School. \\ University of Chile \\ Sergio Livingstone (ex-Olivos) 943, Independencia \\ Santiago - Chile \\ E-mail: iyevenes@odontologia.uchile.cl
}

Received: December 30, 2009

Accepted: May 11, 2010

Conflict of Interest Statement: The authors state that there are no financial and personal conflicts of interest that could have inappropriately influenced their work.

Copyright: (C) 2010 Yévenes et al.; licensee EDIPUCRS. This is an Open Access article distributed under the terms of the Creative Commons AttributionNoncommercial-No Derivative Works 3.0 Unported License. 


\section{Introduction}

Studies of the levels of urinary excretion of fluoride (F) provide important information when monitoring health status and have modified the concentration of fluoride used in food or drink for human consumption. Thus, this process becomes part of Public Health for evaluation of those programs and establishes relationships between intake dose and possible physiological changes or beneficial effects.

The percentage of fluoride actually absorbed and utilized by the body, also known as bioavailability, is variable. According to the INTA (Institute of Nutrition and Food Technology in Chile), the bioavailability is $100 \%$ in water, drops and tablets; $69 \%$ in milk and $50 \%$ in food in general (1).

The main contributor to the total intake of fluoride is drinking water. In the U.S, approximately $76 \%$ of the fluoride ingested by the population comes from water and non-dairy beverages (soft drinks) (2,3). However, it is important to take into consideration all potential sources. One of these sources includes toothpaste because it has a strong contributor to the total fluoride intake (4).

In 2001, the Institute of Medicine, Food and Nutrition Board (USA), determined that there is an optimal dose of systemic fluoride, which gives the maximum benefit, when compared to dental caries level. Based on empirical data, the optimal dose range is 0.05 to $0.07 \mathrm{mg} \mathrm{F} / \mathrm{kg} /$ day (5).

Fluoride absorption is rapid and depending on its bioavailability, is delivered directly to the circulatory system. Studies indicate that $50 \%$ of fluoride absorbed is excreted in the urine 24 hours after ingestion, and the rest is retained in mineralized tissues $(6,7)$.

The renal excretion of the fluoride ion ranges from $30 \%$ to $85 \%$ in children between 3 and 5 years. Regarding this, it has been determined that in general, the higher the fluoride intake, age and urine flow, the greater the fluoride excretion (8-12).

In Chile, approximately $66.3 \%$ of the population receives public water with a fluoride concentration of $0.6 \mathrm{mg} / \mathrm{L}$ (ppm), and the majority of this population are residents of the metropolitan area. Among these communities, Peñalolen has supplemented fluoride in their public water supply since 1996. Moreover, there are still communities in the metropolitan area that are outside this program. One of those is Maipú, which owns an independent drinking-water-network, SMAP, which has only partially implemented fluoridation of the water supply, leaving large sections of the community without this supplement in drinking water $(13,14)$. The purpose of this study was to determine the fluoride intake in preschool children of these two communities.

\section{Methodology}

\section{Characteristics of the Study}

Observational, Cross-sectional. The sample was composed of 200 children attending four kindergarten schools belonging to the board of the National Kindergartens (JUNJI) of the Santiago Metropolitan Region, in Chile. Two schools were located in the commune of Maipú (Emanuel and Small Explorers) and two schools in the commune of Peñalolen (World of Children and Nest-Condors). From each kindergarten school, 50 children between 3 and 5 years old were selected, and the age distribution is displayed in Table 1. The age of the children was considered as completed years from the date of the examination, i.e., a 3 year-old child was considered the age from 3 years and 0 months until 3 years, 11 months and 30 days. The correlation between weight and age are shown in Table 2.

Table 1. Distribution of the study population for kindergarten, community, age and sex.

\begin{tabular}{llcccccc}
\hline \multirow{2}{*}{ Commune } & \multirow{2}{*}{ Kindergarten } & Total & \multicolumn{3}{c}{ Age (Years) } & \multicolumn{2}{c}{ Sex (\%) } \\
\cline { 5 - 8 } & & $(\mathbf{N})$ & 3 & 4 & 5 & Male & Female \\
\hline Maipú & Small Explorers & 50 & 22 & 24 & 4 & 48 & 52 \\
Maipú & Emanuel & 50 & 23 & 20 & 7 & 48 & 52 \\
Peñalolen & Nest-Condors & 50 & 23 & 23 & 4 & 54 & 46 \\
Peñalolen & World of Children & 50 & 24 & 22 & 4 & 44 & 56 \\
& & 200 & 92 & 89 & 19 & 50.5 & 49.5 \\
\hline
\end{tabular}

Table 2. Average body weight (in $\mathrm{kg}$ ) for each kindergarten, by age group.

\begin{tabular}{ccccccccc}
\hline \multirow{2}{*}{$\begin{array}{c}\text { Age } \\
\text { (in years) }\end{array}$} & \multicolumn{2}{c}{$\begin{array}{c}\text { Small Explorers } \\
\text { (Maipú) }\end{array}$} & \multicolumn{2}{c}{$\begin{array}{c}\text { Emanuel } \\
\text { (Maipú) }\end{array}$} & \multicolumn{2}{c}{$\begin{array}{c}\text { Nest-Condors } \\
\text { (Peñalolen) }\end{array}$} & $\begin{array}{c}\text { World of Children } \\
\text { (Peñalolen) }\end{array}$ \\
\cline { 2 - 9 } & $\begin{array}{c}\text { Mean } \\
\text { Weight }\end{array}$ & (SD) & $\begin{array}{c}\text { Mean } \\
\text { Weight }\end{array}$ & (SD) & $\begin{array}{c}\text { Mean } \\
\text { Weight }\end{array}$ & (SD) & $\begin{array}{c}\text { Mean } \\
\text { Weight }\end{array}$ & (SD) \\
\hline 3 & 16.51 & $(2.14)$ & 16.56 & $(2.14)$ & 14.90 & $(1.88)$ & 17.28 & $(2.29)$ \\
4 & 17.64 & $(3.68)$ & 19.10 & $(2.54)$ & 17.49 & $(2.37)$ & 18.19 & $(2.42)$ \\
5 & 19.25 & $(2.87)$ & 19.87 & $(4.55)$ & 18.24 & $(0.35)$ & 19.87 & $(2.96)$ \\
\hline
\end{tabular}


This study was approved by the Ethics Committee of the Faculty of Dentistry of the University of Chile, and the parents of all children accepted participation in the study, signed an informed consent form and verbally confirmed that the residence of the child never changed since birth. The 2003 CASEN survey (Social Economic Characterization Survey) indicated that the target population had low socioeconomic status with a poverty percentage of $10.5 \%$ and $16.7 \%$ for the districts of Maipú and Peñalolen, respectively. The subjects included in the study have good general health and reside in the Maipú or Peñalolen communes of the Metropolitan Region. The exclusion criteria were those children who have changed their commune of residence throughout their lives. Table 2 demonstrates a correlation between weight and age. There is no statistically significant difference between groups $(P>0.05)$. The average body weight was $17.5 \mathrm{~kg}$ for Peñalolen children and $17.6 \mathrm{~kg}$ for Maipú children. The results for the preschools of Peñalolen are similar and were treated as a single population for the analysis. A similar analysis was performed for the children of Maipú.

\section{Procedures}

Plastic bottles labeled with the name of each child were handed to parents, with instructions to collect a morning urine sample. To ensure stability, they were asked to keep the sample refrigerated at home until the time of collection. The dates of urine sample collection were agreed upon by the teachers of each grade. During the collection, urine samples remained at the kindergarten, stored in a cooler with ice close to $\pm 4^{\circ} \mathrm{C}$. The samples were transferred under the same conditions. Each cooler also contained two water samples from different points of the kindergarten. The samples were kept refrigerated until they were processed within the next 72 hours. The process from sample collection to analysis lasted 5 days total. The fluoride and creatinine levels in the urine samples were measured, which provided the daily fluoride intake.

\section{Determination of Fluoride in Urine and Water}

Fluoride in urine and water was determined in potentiometric form, with an ion-specific electrode, according to the technique described by Villa (15), modified by Yévenes et al. (16). $5 \mathrm{ml}$ of TISAB II was added to $5 \mathrm{~mL}$ filtered urine/water and read directly by an ion meter previously calibrated, obtaining readings in $\mathrm{mg} / \mathrm{L}$ (ppm: parts per million) of fluoride.

\section{Creatinine determination}

We used a commercial product by VALTEK, based on the Jaffé reaction (17), where the creatinine mixed with alkaline picrate produces an orange color in proportion to the concentration in the sample and was measured at 510 $\mathrm{nm}$ in a spectrophotometer.

\section{Calculation of excreted fluoride in urine}

We used an equation that relates the ratio of morning fluoride/ creatinine, described by Villa (18) to determine urinary fluoride excretion in preschool children at the community level

Fluoride/creatinine $=-0.13+3.59$ excreted per day

Evaluation of the average daily intake (DDI) of fluoride

We calculated DDI using an equation that relates the ratio of measured fluoride excretion/day (mg/day)/average predicted excretion of fluoride ingested, which is $35.5 \%$ (11), considering the average weight of the group under study.

Determination of daily frequency of toothpaste use and weekly tea consumption

Frequencies were determined from results of a survey, which was answered by parents, guardians and educators. Determination of the daily intake of fluoride from toothpastes was calculated using the equation that relates the ratio between the average daily brushing, the type of paste, the amount of toothpaste used and the intake/body weight. It was assumed that $35.5 \%$ of the paste used is ingested by the children in this age group (15).

\section{Statistical analysis}

Data were analyzed by Statistic 4.5 software (StatSoft, Tulsa, USA) with Student's t-test and analysis of variance at a 0.05 significance level and $95 \%$ confidence interval.

\section{Results}

The results of the urinary parameters of a single morning urine sample for the 200 children studied are shown in Table 3. The value of creatinine is similar between the two samples studied. The value of the fluoride concentration in urine, expressed as $\mathrm{mg} / \mathrm{L}$, shows differences between communities. The population from Maipú exhibited an average of $0.15 \mathrm{mg} / \mathrm{L}$, while in Peñalolen, this value reached $0.51 \mathrm{mg} / \mathrm{L}$, which is significantly higher $(P<0.05)$.

Table 4 shows the results of the excretion study for Maipú and Peñalolen. In Maipú, the excretion average for the group studied is $0.14 \pm 0.11 \mathrm{mg} \mathrm{F} / \mathrm{day}$. According to this value, the total calculated intake for the group was $0.39 \pm 0.25 \mathrm{mg}$ F/day and the daily dose (DDI) reached $0.021 \mathrm{mg} \mathrm{F} / \mathrm{kg}$ $\mathrm{bw} /$ day $\pm 0.010 \mathrm{mg} \mathrm{F} / \mathrm{kg}$ bw/day. The values of excretion for Peñalolen had an average of $0.41 \pm 0.25 \mathrm{mg} F /$ day for the three groups studied; there is an increased contribution of the group of children 3 years of age, which is also observed in the intake values and the daily dose. Values for these parameters indicate that children ingested $1.17 \pm 0.71 \mathrm{mg}$ $\mathrm{F} /$ day, and the daily dose reached $0.066 \pm 0.039 \mathrm{mg} \mathrm{F} / \mathrm{kg}$ bw/day.

Table 5 shows the results for brushing teeth, toothpaste used and intake for both communities, drawn from the parents' survey and nursery schools. All the surveys in both communities reported use of toothpaste on toothbrush at home and in the kindergarten, whereas in all preschools, only children toothpaste was used. At home, the use of child 
toothpaste reaches similar values in Maipú and Peñalolen, $77 \%$ and $79 \%$ respectively. About $23 \%$ of the children in Maipú occasionally used adult toothpaste in the household. This value is equivalent to Peñalolen, reaching $24 \%$. The average frequency of brushing was 3.15 times per day in both communities. In relation to the amount of toothpaste used, the "pea size" was selected by $100 \%$ in all four kindergartens. At home, the same size category reached $60 \%$ in Maipú and $73 \%$ in Peñalolen. The category of "medium brush" is slightly higher in Maipú (37\%) than in Peñalolen $(21 \%)$. The "brush all" presented minimum values in both communes. The ingestion of toothpaste is similar in both communes, $31 \%$ in Maipú and 33\% in Peñalolen. These values are an average intake between home and school. In this study, no significant differences between home or kindergarten $(P>0.05)$ intakes were found. The estimated dose of daily intake of fluoride from toothpastes was 0.019 $\mathrm{mg} \mathrm{F} / \mathrm{kg}$ bw/day for Maipú and $0.017 \mathrm{mg} \mathrm{F} / \mathrm{kg}$ bw/day for Peñalolen. Values are explained by the similarity in the measured parameters as type and quantity of paste and frequency of use. All subjects reported no tea consumption in the kindergarten. Tea consumption at home was similar in both communities, reaching $49 \%$ in Maipú and $44 \%$ in Peñalolen, whereas the average number of cups per day was less than one cup, 0.8 and 0.55 , respectively (Table 6).

Table 3. Urinary parameters, average values.

\begin{tabular}{lccccccccc}
\hline & \multicolumn{4}{c}{$\begin{array}{c}\text { Maipú } \\
\text { Age in years }\end{array}$} & \multicolumn{4}{c}{$\begin{array}{c}\text { Peñalolén } \\
\text { Age in years }\end{array}$} \\
\cline { 2 - 10 } & $\mathbf{3}$ & 4 & 5 & Average & 3 & 4 & 5 & Average \\
\hline Fluoride (mg/L) & 0.13 & 0.17 & 0.14 & 0.15 & 0.46 & 0.54 & 0.62 & 0.51 \\
Mean (SD) & $(0.08)$ & $(0.18)$ & $(0.07)$ & $(0.13)$ & $(0.27)$ & $(0.30)$ & $(0.17)$ & $(0.28)$ \\
Creatinine (g/L) & 0.39 & 0.50 & 0.57 & 0.45 & 0.35 & 0.51 & 0.58 & 0.44 & $(0.19)$ \\
Mean (SD) & $(0.12)$ & $(0.11)$ & $(0.15)$ & $(0.13)$ & $(0.16)$ & $(0.17)$ & $(0.19)$ & $(0.17)$ \\
\hline
\end{tabular}

Table 4. Urinary parameters of the children according to age group in Maipú and Peñalolen.

\begin{tabular}{|c|c|c|c|c|c|c|c|c|}
\hline & \multicolumn{4}{|c|}{ Maipú } & \multicolumn{4}{|c|}{ Peñalolen } \\
\hline & \multicolumn{3}{|c|}{ Age } & \multirow{2}{*}{ Average } & \multicolumn{3}{|c|}{ Age } & \multirow{2}{*}{ Average } \\
\hline & 3 & 4 & 5 & & 3 & 4 & 5 & \\
\hline $\begin{array}{l}\text { Excretion (mgF/day) } \\
\text { Mean (SD) }\end{array}$ & $\begin{array}{c}0.15 \\
(0.12)\end{array}$ & $\begin{array}{l}0.14 \\
(0.11)\end{array}$ & $\begin{array}{c}0.11 \\
(0.04)\end{array}$ & $\begin{array}{c}0.14 \\
(0.11)\end{array}$ & $\begin{array}{c}0.46 \\
(0.30)\end{array}$ & $\begin{array}{c}0.35 \\
(0.17)\end{array}$ & $\begin{array}{c}0.38 \\
(0.17)\end{array}$ & $\begin{array}{c}0.41 \\
(0.25)\end{array}$ \\
\hline $\begin{array}{l}\text { Intake (mgF/day) } \\
\text { Mean (SD) }\end{array}$ & $\begin{array}{c}0.39 \\
(0.20)\end{array}$ & $\begin{array}{l}0.40 \\
(0.32)\end{array}$ & $\begin{array}{c}0.31 \\
(0.11)\end{array}$ & $\begin{array}{c}0.39 \\
(0.25)\end{array}$ & $\begin{array}{c}1.36 \\
(0.86)\end{array}$ & $\begin{array}{c}0.99 \\
(0.51)\end{array}$ & $\begin{array}{c}1.09 \\
(0.50)\end{array}$ & $\begin{array}{c}1.17 \\
(0.71)\end{array}$ \\
\hline $\begin{array}{l}\text { DDI } *(\mathrm{mgF} / \mathrm{kg} / \text { day }) \\
\text { Mean (SD) }\end{array}$ & $\begin{array}{c}0.022 \\
(0.017) \\
\end{array}$ & $\begin{array}{c}0.020 \\
(0.011) \\
\end{array}$ & $\begin{array}{c}0.017 \\
(0.062)\end{array}$ & $\begin{array}{c}0.021 \\
(0.010)\end{array}$ & $\begin{array}{c}0.077 \\
(0.045) \\
\end{array}$ & $\begin{array}{c}0.056 \\
(0.031) \\
\end{array}$ & $\begin{array}{c}0.057 \\
(0.029) \\
\end{array}$ & $\begin{array}{c}0.066 \\
(0.039) \\
\end{array}$ \\
\hline
\end{tabular}

* DDI: Daily Dose Ingestion.

Table 5. Toothpaste type, quantity and intake in brushing teeth in kindergarten and the home in Maipú and Peñalolen.

\begin{tabular}{lccccccccc}
\hline \multirow{2}{*}{ Place } & \multicolumn{1}{c}{ Toothbrushing } & \multicolumn{2}{c}{ Toothpaste Type (\%) } & & Quantity (\%) & \multicolumn{2}{c}{ Intake (\%) } \\
\cline { 2 - 9 } & $N^{\circ}$ time/day & Infant & Adult & Both & Pea & Middle Brush & All & No & Yes \\
\hline Maipú & & & & & & & & & \\
$\quad$ Kindergarten & 1.03 & 100 & 0 & 0 & 100 & 0 & 0 & 67 & 33 \\
$\quad$ Home & 2.12 & 77 & 8 & 15 & 60 & 37 & 3 & 70 & 30 \\
Total & 3.15 & 88.5 & 4 & 7.5 & 80 & 18.5 & 1.5 & 69 & 31 \\
Peñalolen & & & & & & & & & \\
$\quad$ Kindergarten & 1.05 & 100 & 0 & 0 & 100 & 0 & 0 & 73 & 27 \\
$\quad$ Home & 2.10 & 79 & 13 & 11 & 73 & 21 & 6 & 61 & 39 \\
Total & 3.15 & 89.5 & 6.5 & 5.5 & 86.5 & 10.5 & 3 & 67 & 33 \\
\hline
\end{tabular}

Table 6. Daily intake of tea at home for the total sample of children.

\begin{tabular}{lccc}
\hline \multicolumn{1}{c}{ Commune } & No (\%) & Yes (\%) & $\mathrm{N}^{\circ}$ mugs/day \\
\hline Maipú & 51 & 49 & 0.8 \\
Peñalolén & 56 & 44 & 0.55 \\
Total & 53.5 & 46.5 & 0.67 \\
\hline
\end{tabular}




\section{Discussion}

The municipality of Maipú, which has no fluoridation program for the public water supply, showed an average fluoride concentration of $0.1 \mathrm{ppm}$ between the two kindergartens analyzed in this study. The "Emanuel" kindergarten presented a concentration of $0.1 \mathrm{mg} / \mathrm{L}(\mathrm{ppm})$ fluoride, while in "Small Explorers", it was of $0.09 \mathrm{mg} / \mathrm{L}$. These values are lower than those reported by Villa in 1996 for the metropolitan area prior to the program "Fluoridation of water consumption" ( $0.20 \mathrm{mg} / \mathrm{L}$ fluoride) (19).

The "World of Children" and "Nest-Condors" kindergarten of Peñalolen showed a concentration of $0.45 \mathrm{mg} / \mathrm{L}$ and $0.5 \mathrm{mg} / \mathrm{L}$ fluoride in the water consumed, respectively, giving an average of $0.48 \mathrm{mg} / \mathrm{L}$ fluoride. Regarding this commune, the MINSAL reported in 2004 a concentration of $0.67 \mathrm{mg} / \mathrm{L}$, higher than the value found in this study. All values were obtained by taking two samples of drinking water at different sites of each educational venue. The data in this study shows a clear difference in the amount of available fluoride intake through water consumption.

Values of DDI in the municipality of Maipú was higher than those reported in Japanese children between 1 and 6 years ( $0.019 \mathrm{mg} \mathrm{F} / \mathrm{kg}$ bw/day) (20), but lower than the nonfluoridated communities in New Zealand $(0.027 \mathrm{mg} \mathrm{F} / \mathrm{kg}$ bw/day) (21) and in children 3 and 4 years of age and in nonfluoridated areas of the northeast of England $(0.031 \mathrm{mg} \mathrm{F} / \mathrm{kg}$ bw/day) (22), although all these values are lower than the recommended DDI, between 0.05 to $0.07 \mathrm{mg} \mathrm{F} / \mathrm{kg}$ bw/day (5). In the fluoridated commune of Peñalolen, the value $0.066 \mathrm{mg} \mathrm{F} / \mathrm{kg}$ bw/day was similar to the DDI found in the study in 2000 (11), but higher than the $0.036 \mathrm{mg} \mathrm{F} / \mathrm{kg}$ bw/day found in children 3 and 4 years old in fluoridated areas of New Zealand (21), the $0.047 \mathrm{mg} \mathrm{F} / \mathrm{kg}$ bw/day found in English children in fluoridated areas (22) and the
$0.053 \mathrm{mg} \mathrm{F} / \mathrm{kg}$ bw/day in German children (23). Groups of children 4 to 5 years old in this study were found in the recommended ranges of DDI, whereas the group that was three years of age was located on the optimum. These findings are consistent with other studies that compare fluoride intake in children in relation to weight body decreases (20).

The daily dose of fluoride ingested from toothpastes was $0.019 \mathrm{mg} \mathrm{F} / \mathrm{kg}$ bw/day for Maipú and $0.017 \mathrm{mg} \mathrm{F} / \mathrm{kg}$ bw/day for Peñalolen. This was similar to previous studies in 1996 (19) and 2004 (14), which reported values reaching 0.025 and $0.017 \mathrm{mg} \mathrm{F} / \mathrm{kg} \mathrm{bw} /$ day, respectively. However, a recent study investigating the fluoride intake from toothpaste in 1- to 3 -year-old Brazilian children (4), reported $0.106 \pm 0.085 \mathrm{mg}$ $\mathrm{F} / \mathrm{kg}$ bw/day and speculated that this different contribution of toothpaste may be due to the higher fluoride concentrations found in toothpaste; age differences of the study population, as younger children are more likely to swallow toothpaste; or differences in the methods of estimating the fluoride intake from toothpaste.

In relation to tea intake, the results indicate that $46.5 \%$ of the total population consumes tea, with an average of 0.67 cups per person per day. These figures are lower than those described by the MINSAL in 2004 (56.69\% of intake) and Campos in 2006 (61.2\%) (24), although the frequency is similar, as that study reached 0.68 cups per person per day. This infusion is an important source of fluoride and, in our population, is a significant part of the daily diet of a significant percentage of the children studied.

\section{Conclusions}

The ingestion of fluoride from water and other sources in the preschool commune of Peñalolen is much higher than the intake of preschoolers in the commune of Maipú.

\section{References}

1. Institute of Nutrition and Food Technology 1985. "Bioavailability of fluoride: a study of the fluoride level". First Symposium on Fluorides. INTA. U de Chile, Santiago.

2. Fomon SJ, Ekstrand J, Fluoride Intake. In: Fejerskov O, Ekstrand J, Burt B, (eds). Fluoride in Dentistry. Copenhague: Munksgaard; 1996. p.40-52.

3. Subba-Rao G. Dietary intake and bioavailability of fluoride. Am Rev Nutr 1984;4:115-36.

4. de Almeida BS, da Silva Cardoso VE, Bufazalaf MAR. Fluoride ingestion from toothpaste and diet in 1- to 3-year-old Brazilian children. Community Dent Oral Epidemiol 2007;35:53-63.

5. Institute of Medicine, Food and Nutrition Board. Dietary reference intakes (DRIs): Applications in Dietary Assessment. Washington DC: National Academy Press, 2001.

6. Whitford GM. The metabolism and toxicity of fluoride. In: Myers HM (ed) Monographs in oral science. S.Karger, Basel. 1996. p.10-29.

7. Whitford GM. The metabolism and toxicity of fluoride. In: Myers HM (ed) Monographs in oral science. S.Karger, Basel. 1996. p. $1-9$.
8. Grijalva-Haro MI, Barba-Leiva ME, Laborin-Alvarez A. Fluoride intake and excretion among children in Hermosillo, Sonora, Mexico. Salud Pública Mex 2001;43:127-34.

9. Zohouri F V, Rugg-Gunn AJ. Total fluoride intake and urinary excretion in 4 -year-old Iranian children residing in low-fluoride areas. Br J Nutr 2000;83:15-25.

10. Haftenberg M, Viergutz G, Neumeister V, Hetzer G. Total fluoride intake and urinary excretion in german children aged $3-6$ years. Caries Res 2001; 35:451-7.

11. Villa $A E$, Anabalón M, Cabezas L. The fractional urinary fluoride excretion in young children under stable fluoride intake conditions. Community Dent Oral Epidemiol 2000;28:344-55.

12. Gómez S. Fluoride therapy in dentistry for children and adolescents. 3.ed. Por Grant Educacional Colgate. Santiago, 2001.

13. Villa $A E$, Guerrero S, Villalobos J. Estimation of optimal concentration of fluoride in drinking water under conditions prevailing in Chile. Community Dent Oral Epidemiol 1998;26:249-55.

14. MINSAL Dental Department. Report of progress of the national Fluoridation of drinking water. Santiago: Chilean Health Ministry; 2004. 
15. Villa A. Rapid method for determining very low fluoride concentrations using a ion selective electrode. Analyst 1988;113: 50-6.

16. Yévenes I, Reyes J, Sánchez U, Sanza H. Study and determination of fluoride, triclosan and zinc citrate dentifrices double action. Av Odonto Estomatol 1999;15:433-44.

17. Bonsnes RW, Taussky HH. Colorimetric on the determination of creatinine by the Jaffe reaction. J Biol Chem 1945;158: $581-91$.

18. Villa A. A new method for determining fluoride excretion in preschool children at the community level. Odontol Chil 1994; 42:28-31

19. Villa A, Salazar G, Andrade M, Villa C, Anabalón M, Cabezas S et al. Study of urinary excretion and the use of toothpastes and other sources of fluoride in children pre-school, regions II, VI, VIII, IX, X and RM. Chilean Health Ministry; 1996.
20. Kimura T, Morita M, Kinoshita T, Tsuneishi M, Akagi T, Yamashita F et al. Fluoride intake from food and drink in Japanese children aged $1-6$ years. Caries Res 2001; 35:47-49.

21. Guha-Chowdhury N, Drummond BK, Smillie AC. Total fluoride intake in children aged 3 to 4 years- a longitudinal study. J Dent Res 1996; 75:1451-7.

22. Maguire A, Zohouri FV, Hindmarch PN, Hatts J, Moynihan PJ. Fluoride intake and urinary excretion in 6 to 7 -years-old children living in optimally, sub-optimally and non-fluoridated areas. Community Dent Oral Epidemiol 2007; 35:479-88.

23. Haftenberger M, Viergutz G, Neumeister V, Hetzer G. Total fluoride intake and urinary excretion in German children aged 3-6 years. Caries Res 2001; 35;451-7.

24. Yevenes I, Campos B, Apip A, Espinoza RM, Jara MN, Smith LP. Prevalence of dental caries in preschool children in Peñaflor, Santiago, Chile. Rev Odont Cienc 2009; 24:116-9. 